Tezden Türetilmiş Makale

\title{
Sözsüz İletişim Becerilerinden Öğretmenlerin Öğrencilerle Göz Teması Kurma Davranışlarının Bazı Değişkenler Açısından Değerlendirilmesi ${ }^{\star}$
}

\author{
Serkan Düzgün (Dr.) \\ serkanduzgun@hotmail.com \\ Ziya Selçuk (Prof. Dr.) \\ Gazi Üniversitesi Eğitim Fakültesi \\ ziyaselcuk1@yahoo.com
}

Başvuru Tarihi: 04.05.2018

Yayına Kabul Tarihi: 30.07.2018

Yayınlanma Tarihi: 30.07.2018

\section{Öz}

Araștırmanın temel amacı; sınıf öğretmenlerinin derste öğrencileriyle göz teması kurma davranışlarını ve bu davranışları hakkındaki görüşlerini, meslekî kıdemlerine, cinsiyetlerine, algısal öğrenme stillerine ve öğrencilerinin akademik başarı düzeyleri ile cinsiyetlerine göre incelemektir. Kıdem değişkenine göre odaklanma süresi anlamlı olarak farklılaşmaktadır ( $\mathrm{p}=0,039)$. Ancak, odaklanma sayısı kıdeme göre anlamlı bir farklılık göstermemektedir $(p=0,336)$. Başka bir anlatımla, sınıf öğretmenlerinin kıdemi, odaklanma süresini anlamlı düzeyde etkileyen bir faktörken, odaklanma sayısını anlamlı düzeyde etkileyen bir faktör olmadığı söylenebilir. Öğretmenlerin öğrenme stilleri değişkenine göre odaklanma süresi anlamlı olarak farklılaşmaktadır $(p=0,004)$. Ancak, odaklanma sayısı öğretmenlerin öğrenme stillerine göre anlamlı bir farklılık göstermemektedir $(p=0,199)$. Öğrenci odaklanma süresi $(p=0,031)$ ve odaklanma sayısı $(p=0,022)$ öğrenci not ortalaması değişkenine göre anlamlı bir farklılık göstermektedir. Son olarak araştırma sonucunda elde edilen bulgulara göre öğretmenlerin büyük çoğunluğunun derste öğrencileriyle gerçekleştirdikleri göz teması kurma davranışları ile öğrencilerin akademik başarı düzeyleri arasında ilişki ve etkileşimi olduğu düşünülmektedir.

$\mathrm{Bu}$ araştırma sonucunda, öğretmenlerin hem kendileri hem de her bir öğrencinin algısal öğrenme tercihini tespit etmesi ve bu tercihlere göre göz teması kurma davranışını yönetmeye çalışması önerilebilir.

Anahtar Kelimler: Sözsüz İletişim, Göz Teması, Göz İzleme Sistemi, Göz İzleme Testi, Algısal Öğrenme Stilleri, Meslekî Kıdem.

\footnotetext{
* Bu çalışma, Gazi Üniversitesi Eğitim Bilimleri Enstitüsü’ne 2015 yılında Serkan Düzgün tarafından sunulan, "Sınıf Öğretmenlerinin
} Göz Teması Kurma Davranışlarının Bazı Değişkenlere Göre İncelenmesi” başıkıı Doktora tezinden türetilmiş makaledir. 


\title{
Analysing Theacher's Eye-Contact Behaviours of Nonverbal Communication Based on Some Variables
}

\author{
Serkan Düzgün (PhD) \\ serkanduzgun@hotmail.com \\ Ziya Selçuk (Prof. Dr.) \\ Gazi University Faculty of Education \\ ziyaselcuk1@yahoo.com
}

Date Received: 04.05.2018

Date Accepted: 30.07.2018

Date Published: 30.07.2018

\begin{abstract}
The main objective of the present study is to analyze eye contact behaviors of classroom teachers during the class and their opinions about such behaviors of them based on their professional seniority, gender, perceptional learning styles and level of academic achievement of their students. There is a statistically significant difference in focusing time based on the seniority variable $(p=0,039)$. However, there is no statistically significant difference in the number of focusing based on the seniority variable. $(p=0,336)$. There is a statistically significant difference in focusing time based on the teachers' learning styles variable $(p=0,004)$. However, there is no statistically significant difference in the number of focusing based on the teachers' learning styles $(p=0,199)$. There is a statistically significant difference in focusing time $(p=0,031)$ and number of focusing $(p=0,022)$ the mean score of students shows a significant difference. Finally, according to the findings of the research, it is seen that the majority of the teachers think that the eye-building behaviors performed by the students are the relationship and interaction between the students' academic achievement levels.
\end{abstract}

As a result of this research, it may be advisable for teachers to identify perceptual learning preferences for themselves and for each student, and to try to manage the behavior of eye contact according to these preferences.

Keywords: Nonverbal communication, eye contact, eye tracking system, eye tracking test, perceptional learning styles, professional seniority. 


\section{Giriş}

Sözlü mesajların yorumlanmasında karşıdaki kişiye önemli ipuçları veren sözsüz iletişim daha güvenilir bir iletişim yöntemi ve kişilerarası iletişimde etkili bir mesaj kaynağıdır (Özbent, 2007, 261). Bu nedenle günlük hayatın içinde iletişim eksikliklerinden kaynaklanan çatışmaların önlenmesinde insanların sözsüz iletişim becerilerini etkili kullanmayı öğrenmeleri oldukça önemlidir (Poon, Teng ve Fatt 2001, 24; Çuhadar, Özgür, Akgün ve Gündüz, 2014, 298). Özellikle kişilerarası iletişimin oldukça yoğun olduğu eğitim ve öğretim kurumlarında öğrencilerden gelen sözel olmayan mesajları anlamlandırmak, öğretmenlerin mesleğinde başarılı olabilmeleri açısından oldukça önemlidir (Senemoğlu, 2012, 36; Deniz, 2015a, 64-65).

Ses ve sözcüklerin kullanılmadığı tüm beden hareketlerini kapsayan sözsüz iletişim, insanların birbirlerine, duygularını, düşüncelerini ve mesajlarını aktarmasına yardımcı olan en etkili iletişim boyutudur. İnsan bedeninin çeşitli hareketlerine, ifadelerine ve değişimlerine göre şekillenen sözsüz iletişim becerilerinin içerisinde en dikkat çekeni gözle gerçekleşen iletişim davranışlarıdır (Akpınar, 2006, 2). Göz teması kurma davranışı, insanların gördüğü bir nesneye ne derece ilgi duyduğuyla ilgili mesajlar veren, insanların zihinlerinden geçen düşünceleri dişa vurmaya yardımcı olan ve farklı davranışların nedenlerini güvenilir bir şekilde açıklayan en etkili sözsüz iletişim yollarından biridir. Bu yolla insanların iç dünyasında oluşan, birbirinden farklı duygular ifade edilmeden sessiz mesajlar halinde dış dünyaya yansıtarak iletişime geçilebilmektedir (Baltaş ve Baltaş, 2015, 13). Dolayısıyla insanların göz teması davranışlarının insanlar arasındaki iletişim süreçlerinde kullanılan en etkili ve en önemli iletişim aracı olduğunu söylemek mümkündür (Cüceloğlu, 2015, 22).

İnsanların gördüğü bir nesneye ne derece ilgi duyduğunu, o nesneden hoşlanmadığını ya da karşısındakinden bir şeyler saklama çabasında olduğunu sadece gözün hareketlerine ve göz teması kurma davranışlarına bakarak söylemek mümkündür (Kaşıkçı, 2004, 16). Sadece gözün hareketlerine bakarak ve insanların göz teması kurma hakkındaki görüşlerini dinleyerek, zihinlerden geçen düşünceleri, dışa vurdukları davranışların nedenlerini ve kişilerarası iletişim süreçlerinde karşısındakilere iletmek istedikleri tüm sessiz mesajları net bir şekilde anlamak mümkündür (Yavuzer ve Koç, 2002, 38). Özellikle teorik düzeyde yapılan ve öğretmenlerin sözsüz iletişim becerisini konu alan araştırmalarda genellikle ögretmenlerin ders anlatımlarında beden dilini kullanmasının önem ve değeri üzerinde durulduğu (Vatansever, 2015, 262-263); ancak bu tür çalışmalarda bile öğretmenlerin sözsüz iletişim becerilerinden sadece onların sözlü ders anlatımını destekleyen bir unsur olarak bahsedildiği görülmüştür (Deniz, 2013, 530; Çuhadar vd., 2014, 299; Deniz, 2015a, 67; Deniz, 2015b, 455)

Öğretmenlerin öğretim süreçlerinde göz teması kurma davranışını etkili bir şekilde kullanabilmesi için, onların bu davranışlarını etkileyen değişkenlerin tespit edilmesi ve bu tür tespitler ışığında göz teması kurma davranışını başarılı bir şekilde yönetecek yönetsel stratejiler geliştirmesi gerekmektedir (Ergin ve Birol, 2014, 121). Bunun için göz kapaklarını kapatmakla ancak gizlenebilen, dille söylenmeyen düşünceleri bile açığa vuran, öfke, mutluluk, üzüntü, sevinç, kin, nefret, kibir ve benzeri duygulara göre aniden değișebilen göz hareketleri nicel ve nitel yöntemlerle incelenmelidir. 
Bacanlı (2015), göz temasının etkili kullanımının okullarda etkili sınıf yönetimi ortamı oluşturmaya katkı sağladığını ve daha önemlisi de öğretmenlerin öğrencileriyle arasındaki ilişkileri pozitif yönde geliştirdiğini belirtmektedir (Bacanll, 2015, 26).

Ergin ve Birol (2014)'un yaptığı çalışmada öğretmenlerin öğrencileriyle aralarında gerçekleşen başta göz teması olmak üzere tüm sözsüz iletişim davranışları, gerek etkili sınıf yönetimi açısından gerekse öğrencilerin akademik başarı düzeylerini arttırmak açısından kapsamlı bir şekilde araştırılmaya ve incelenmeye değer bir konu olduğunu savunmuştur (Ergin ve Birol, 2014, 121-122).

Gürgen (1997)'e göre ise sözsüz iletişimin en temel kaynağı olan göz teması kurma davranışı, kişilerarası iletişim süreçlerinde başlı başına birer sözsüz mesajlaşma yöntemi olarak kullanılan, insanların içinden geçenleri samimi ve açık bir şekilde anlatmaya yarayan bir iletişim tekniğidir (Gürgen, 1997, 39).

$\mathrm{Bu}$ araştırmada öğretmenlerin göz teması kurma davranışları; onların meslekî kıdemleri, cinsiyetleri, algısal öğrenme stilleri, öğrencilerin cinsiyetleri ve başarıları gibi değişkenlerle incelenmiştir. Literatürde, özellikle Türkiye'de bu tür araştırmaların yaygın olduğunu söylemek güçtür. Öğretmenlerin cinsiyetlerine ve meslekî kıdemlerine göre gelişen deneyimlerinin öğrencileriyle arasındaki göz teması davranışlarına etkisi olup olmadığı henüz bilinmeyen ve araştırılması gereken bir konudur. Benzer şekilde hem öğretmenlerin hem öğrencilerin doğuştan sahip oldukları algısal öğrenme stillerinin onların göz teması kurma davranıșı üzerinde etkisinin olup olmadığı konusu da halen merak edilen, ancak bilimsel araştırmalarla henüz açıklanmayan önemli bir araştırma konusudur.

$\mathrm{Bu}$ araştırma, elde edilecek bulgularla öğretmenlerin öğrencileriyle göz teması yoluyla kurdukları sözsüz iletişim becerilerini geliştirmeye yönelik çeşitli stratejiler önerilebilecektir. Bu doğrultuda mesleki kıdemleri farklı olan öğretmenlerin göz teması kurma davranışı üzerinde farkındalık oluşturmaları ve göz temasını yoğun kullanan öğretmenlerden bilgi ve deneyim paylaşımı yapmaları öğrencilerle göz teması kurma davranışlarını geliştirmeleri açısından önemlidir. Ayrıca insanların yaşamlarını etkileyen algısal öğrenme stillerinin göz teması kurma davranışları üzerine de etkisi ortaya konulmaktadır. Kıdem faktöründe olduğu gibi; öğretmenlerin kendi algısal öğrenme stillerini tespit etmeleri ve kendileri üzerindeki etkilerini anlamaları öğretim süreçlerindeki davranışlara etki edecektir. Özellikle göz teması kurma davranışlarını kullanmaları açısından algısal öğrenme stillerini bilerek kendilerini yönlendirmeleri öğrencilerin başarılarını etkileyen bir faktör olduğu da ortaya çıkmaktadır. Sonuçta; öğretmenlerin mesleki kıdemleri ve algısal öğrenme stilleri ile göz teması kurma davranışlarının ilişkisini ortaya koymak, öğretmenlere farkındalık oluşturmak ve onları yönlendirmek açısından önem taşımaktadır. Ayrıca araştırmada öğretmenlerin öğrencilerle etkileşimi merkeze alınmıştır. Bu durumda gerçekleştirilen ölçümlerde öğretmen ve öğrencilerin cinsiyetleri de araştırmaya konu edinmiş ve göz teması kurma davranışı ile ilişkisi ortaya konulmaya çalışılmıştır. $\mathrm{Bu}$ açıdan bir durum çalışması gerçekleştirilmiştir. Bunun yanında öğrenci başarı durumlarının göz teması kurma davranışına etkisi incelenmiş ve göz teması kurma davranışının önemi ortaya konulmuştur.

$\mathrm{Bu}$ araştırmayı önemli kılan diğer bir husus, araștırmada kullanılan veri toplama yöntemiyle ilgilidir. Genellikle pazarlama araştırmaları, web sayfası tasarımları, 
kullanılabilirlik testleri gibi araştırmalarda yaygın bir şekilde kullanılan, saliseler içinde meydana gelen göz hareketlerini, kamera ve bilgisayar yardımıyla kayıt altına alan göz izleme teknolojileri, insan gözünün tüm odaklanmaları, kaymaları ve sıçramaları ile hangi sıklıklarla ve ne kadar süreyle bir nesneye baktığını ölçebilmektedir (Pernice ve Nielseni, 2009). Ayrıca göz izleme teknolojilerinin veri toplama aracı olarak kullanıldığı araștırmalara bakıldığında insanların göz hareketlerinin genellikle bilgisayar ekranına, kapı, resim, yazı veya kitap gibi cansız nesnelerebakmakveya odaklanmaksuretiyle yapıldığıgörülmektedir. Buaraștırmada göz izleme sistemleri, canlı varlıklar olan öğrencilerle öğretmenlerin arasındaki göz teması kurma davranışını ölçümlemek üzere kullanılmıştır. Sınıf öğretmenlerinin öğrencileriyle göz teması kurma davranışları göz izleme sistemiyle incelenmiş ve araştırma verilerinin önemli bir kısmı bu yöntemle toplanmıştır. Böylece eğitim ve iletişim alanında öğretmenlerin göz hareketleri ve öğrencilere yönelik göz teması kurma davranışları, sınıf ortamında göz izleme sistemleri aracılığıyla test edilmiş, yapılan testlere ilişkin bulgulara göre değerlendirmeler yapılmıștır.

Sonuç olarak, çalışma kapsamında öğretmenlerin öğrenciler ile göz teması kurma davranışlarının ölçümlemesi gerçekleştirmiştir. Çalışma sonunda elde edilen bulguların özellikle eğitim ve iletişim alanlarında yeni araştırmalara da önemli bir perspektif sunabileceğini düşünmekteyiz.

Bu amaçla çalışmada, aşağıdaki araştırma sorularına cevap aranmıștır;

1. Sınıf öğretmenlerinin derste öğrencileriyle göz teması kurma davranışları ile meslekî kıdemleri arasında anlamlı bir ilişki var mıdır?

2. Sınıf Öğretmenlerinin derste öğrencileriyle göz teması kurma davranışları ile cinsiyetleri arasında anlamlı bir ilişki var mıdır?

3. Sınıf öğretmenlerinin göz teması kurma davranışına yönelik düşünceleri algısal öğrenme stillerine göre nasıl bir değişim göstermektedir?

4. Öğrencilerin derste öğretmenleriyle göz teması kurma davranışları ile cinsiyetleri arasında anlamlı bir ilişki var mıdır?

5. Öğrencilerin derste öğretmenleriyle göz teması kurma davranışları ile başarı düzeyleri arasında anlamlı bir ilişki var mıdır?

6. Öğretmenlerin göz teması kurma davranışları hakkındaki genel görüşleri nelerdir?

\section{Yöntem}

\subsection{Araştırmanın Modeli ve Değişkenleri}

Araștırmada nitel ve nicel yaklaşımların birlikte ele alındığı karma yöntem kullanılmıştır. Nicel yaklaşımda tarama modeli benimsenmiştir. Tarama modeli, geçmişte ya da halen var olan bir durumu var olduğu şekliyle betimlemeyi amaçlayan araştırma yaklaşımıdır. Araştırmaya konu olan olay, birey ya da nesne, kendi koşulları içinde ve olduğu gibi tanımlanmaya çalışılır (Gürbüz ve Şahin, 2015, 360-375). Nitel yaklaşımda ise örnek olay modeli benimsenmiștir. Örnek olay modeli, güncel bir olguyu kendi yaşam çerçevesi (içeriği) içinde çalışan, olgu ve içinde bulunduğu içerik arasındaki sınırların kesin hatlarıyla belirgin olmadığı, birden fazla kanıt veya veri kaynağının mevcut olduğu durumlarda kullanılan görgül bir araştırma yöntemidir (Yıldırım ve Şimșek, 2013, 306). 
Araştırma kapsamında incelenen iki temel bağımlı değişken bulunmaktadır. Araştırma kapsamında incelenen bağımlı değişkenlerin ilki öğretmenlerin göz teması kurma davranışları, ikincisini ise öğretmenlerin göz teması kurma davranışları hakkındaki görüşleridir. Öğretmenlerin; meslekî kıdemleri, cinsiyetleri, algısal öğrenme stilleri ile öğrencilerin, akademik başarı düzeyleri ve cinsiyetleri araştırma kapsamında bağımsız değişkenler olarak analizlere dâhil edilmiştir. Böylece araștırmanın bağımsız değişkenleri ile bağımlı değişkenleri arasında olduğu varsayılan ilişki nicel ve nitel araştırma yöntemleri birlikte kullanılarak tespit edilmeye çalıșılmıştır.

Öteyandanaraştırmamodelindegösterilmeyenancaközelliklebağımsızdeğişkenlerin tespitinde kullanılan bazı "açıklayıcı değişkenler" araştırma kapsamında analizlere dâhil edilmiştir. Örneğin; öğretmenlerin göz teması davranışlarının sıklıkları "odaklanma sayılarına" ve bu davranışlarının süreleri "odaklanma sürelerine" göre açıklanmıştır. Yine göz izleme testine katılan öğrencilerin cinsiyet ve akademik başarı düzeylerinin tespitinde çeşitli açıklayıcı değişkenlerden yararlanılmıştır. Örneğin; akademik yönden başarılı öğrencilerin tespiti için sınıf not ortalamaları sınıf öğretmenlerinin verdikleri ana derslerin yılsonu not ortalamalarından yararlanılarak hesaplanmıștır.

Araştırmada yer alan tüm açıklayıcı değişkenler araştırmanın alt problemlerinin çözümlenmesinde yardımcı rol üstlenmiş olup, araştırmanın bağımlı ve bağımsız değişkenleri olmadıkları için araştırma modelinde gösterilmemiştir.

\subsection{Araştırmanın Çalışma Grubu}

Nitel ve nicel yaklaşımların birlikte kullanıldığı bu araştırmanın örneklem kümesi 12 ( 6 erkek, 6 kadın) sınıf öğretmeninden oluşturmaktadır. Araştırma kapsamında yapılan göz izleme testi, çalışma grubuna ve diğer anket çalışmalarına katılan öğretmen grubu, özel ve devlet ilköğretim okullarında aktif olarak çalışan sınıf öğretmenleri arasından "amaçlı örnekleme" yoluyla seçilmiştir. Çalışmaya dâhil edilen öğretmenlerin demografik özellikleri Çizelge 1'de özetlenmiştir.

Çizelge 1: Öğretmenlerin Demografik Özellikleri

\begin{tabular}{|l|c|c|c|c|c|}
\hline Öğretmen Kodu & Öğrenci Sayısı & $\begin{array}{c}\text { Meslekî } \\
\text { Kıdem Yılı }\end{array}$ & Cinsiyeti & Kıdem Değişkeni & Okul Türü \\
\hline OGRT1E & 26 & 19 & Erkek & Kıdemli & Devlet \\
\hline OGRT2E & 19 & 23 & Erkek & Kıdemli & Devlet \\
\hline OGRT3E & 27 & 24 & Erkek & Kıdemli & Devlet \\
\hline OGRT4E & 26 & 7 & Erkek & Kıdemsiz & Devlet \\
\hline OGRT5E & 14 & 6 & Erkek & Kıdemsiz & Devlet \\
\hline OGRT6E & 24 & 7 & Erkek & Kıdemsiz & Özel \\
\hline OGRT1K & 29 & 13 & Kadın & Kıdemli & Devlet \\
\hline OGRT2K & 24 & 41 & Kadın & Kıdemli & Özel \\
\hline OGRT3K & 20 & 13 & Kadın & Kıdemli & Özel \\
\hline OGRT4K & 21 & 7 & Kadın & Kıdemsiz & Özel \\
\hline OGRT5K & 19 & 1 & Kadın & Kıdemsiz & Özel \\
\hline OGRT6K & 17 & 3 & Kadın & Kıdemsiz & Özel \\
\hline 12 Sınıf Öğretmeni & 266 Öğrenci & & $6+6=12$ & $6+6=12$ & $6+6=12$ \\
\hline
\end{tabular}

Öğretmenlerin demografik özellikleri göz önünde bulundurularak öğretmenlerin göz teması davranışları incelenmiş olup, özellikle öğretmenlerin kıdem, 
cinsiyet ve algısal öğrenme stillerine ilişkin değişkenlerin dağılımları aşağıdaki Çizelge 2'de gösterilmiştir.

Martin ve ark. (1998), kıdemli öğretmeni, öğretmenlik alanı üzerinde özel bilgi ve deneyime sahip kişi olarak, kıdemsiz öğretmenin ise; öğretmenlik alanında yeni ve seçilmiş bir konu üzerinde çok az deneyime sahip kişi olarak tanımlamaktadır (Martin ve ark. 1998, 615). Araștırma kapsamında kıdemli öğretmenlerin 8 yıl ve daha fazla meslekî kıdeme sahip olduğunu, kıdemsiz öğretmenlerin ise 0-7 yıl meslekî kıdeme sahip olduğunu ifade etmişlerdir. Böylece göz izleme testine katılan öğretmenlerin seçiminde meslekî kıdem ve cinsiyet değişkenlerine göre dengeli bir dağılım olmasına dikkat edilmiş, bu doğrultuda aşağıdaki Çizelge 2'de detayları verilen öğretmenlerin göz izleme testine katılması sağlanmıştır.

Çizelge 2: Çalışmaya Dâhil Edilen Öğretmenlerin Kıdem, Cinsiyet ve Algısal Öğrenme Stillerine İlişskin Değisşkenlerin Dağılımları

\begin{tabular}{|l|c|c|c|}
\hline Öğretmen & Cinsiyet & Kıdem & Algısal öğrenme stilleri \\
\hline OGRT1E & Erkek & Kıdemli & İşitsel-Kinestetik \\
\hline OGRT2E & Erkek & Kıdemli & Kinestetik \\
\hline OGRT3E & Erkek & Kıdemli & Kinestetik \\
\hline OGRT4E & Erkek & Kıdemsiz & Kinestetik \\
\hline OGRT5E & Erkek & Kıdemsiz & Kinestetik \\
\hline OGRT6E & Erkek & Kıdemsiz & Kinestetik \\
\hline OGRT1K & Kadın & Kıdemli & İşitsel-Kinestetik \\
\hline OGRT2K & Kadın & Kıdemli & Kinestetik \\
\hline OGRT3K & Kadın & Kıdemli & Görsel \\
\hline OGRT4K & Kadın & Kıdemsiz & Görsel \\
\hline OGRT5K & Kadın & Kıdemsiz & İşitsel \\
\hline OGRT6K & Kadın & Kıdemsiz & Görsel-Kinestetik \\
\hline
\end{tabular}

Araștırma kapsamında öğretmenlerin görsel, işitsel ve kinestetik/dokunsal öğrenme stillerini belirlemek amaciyla Neil Fleming (1995, 2001, 2010 ve 2012) tarafindan geliştirilen "VARK Öğrenme Stilleri Envanteri” kullanılmıștır.

\subsection{Araştırmada Kullanılan Veri Toplama Yöntemleri}

Araştırma kapsamında sınıf öğretmenlerinin derste öğrencileriyle kurdukları göz teması davranışlarını ve bu davranışları hakkındaki görüşlerini çeşitli değişkenlere göre tespit etmek amacıyla nitel ve nicel araştırma yöntemleri birlikte kullanılmıștır.

Özellikle sınıf öğretmenlerinin öğrencileriyle göz teması davranışlarını nicel yöntemlerle ölçümlemek üzere, mobil göz izleme cihazından yararlanılmıştır. Araştırma için uygulamalar 2 hafta boyunca çalışma grubunu oluşturan öğretmenlerin çalıştıkları okullarda gerçekleştirilmiştir.

Araștırma kapsamında bağımsız değișkenler olarak analize giren öğrencilerin cinsiyet ve akademik başarı düzeylerini tanımlayan istatistiksel veriler göz izleme testinin yapıldığı okul yönetiminden edinilmiştir. Böylece öğretmenlerin aktif örneklem olarak katıldığı göz izleme testine, pasif örneklem olarak katılan öğrencilerin cinsiyetleri ve akademik başarı düzeyleri tespit edilmiştir.

Öğrencilerin akademik başarı düzeylerini tespit etmek için Türkçe, Matematik, Hayat Bilgisi, Fen ve Teknoloji, Sosyal Bilgiler derslerinden aldıkları yılsonu 
not ortalamalarının aritmetik ortalamaları hesaplanarak, 100 puan üzerinden her bir öğrenci için akademik başarı derecelendirilmesi yapılmıştır. Göz izleme testinin yapıldığı sınıflar ilkokul düzeyinde olması nedeniyle öğrencilerin çoğunun not ortalaması resmi başarı kriterlerinin üstünde bulunmaktadır. $\mathrm{Bu}$ nedenle öğrencilerin akademik başarı değișkeni süreli değişken olarak analiz edilmiştir.

Sonuç olarak bu araştırma kapsamında öğretmenlerin göz teması kurma davranışları hakkında nicel ve nitel veriler toplamak üzere, göz izleme testi, VARK öğrenme stilleri envanteri, yarı yapılandırılmış mülakat tekniğinden ve geriye dönük izleme kayıtları veri toplama yöntemlerinden birlikte yararlanılmıştır.

\subsection{Araştırmada Kullanılan Veri Toplama Araçları}

Araştırmada temel veri toplama aracı olarak, "Mobil Göz İzleme Cihazı (Mobile Eye Tracker)" adı verilen ve kullanıcıların göz hareketlerini ölçümleyen cihaz kullanılmıştır. $\mathrm{Bu}$ cihaz kullanıcının nereye, ne kadar süre ve kaç kere baktığını, anlık ve geçmiş dikkatinin nerede yoğunlaştığını, bakış esnasındayken zihinsel durumunu belirlemek amacıyla kullanılan ve göz hareketlerini takip eden bir cihazdır. Araştırmada SMI markasına ait Eye Tracking Glasses modeli kullanılmıştır

Araştırma kapsamında öğretmenlerin görsel, işitsel ve kinestetik/dokunsal öğrenme stillerini belirlemek amaciyla Neil Fleming (1995, 2001, 2010 ve 2012) tarafindan geliştirilen "VARK Öğrenme Stilleri Envanteri” kullanılmıştır.

İlk olarak 1987 yılında, Yeni Zelanda Lincoln Üniversitesi'nden Neil Fleming tarafından geliștirilen VARK Öğrenme Tercihleri Envanteri yalnızca bireylerin bilgi alışverişlerini nasıl yaptıklarını değil aynı zamanda bireylerin her türlü bilgiyi işleme tercihlerinin neler olduğunu ortaya çıkarmayı da amaçlamaktadır (Hawk ve Shah, 2007).

Söz konusu envanterde çeşitli dönemlerde değişiklikler yapılmakla birlikte Fleming 1995, 2001, 2010 ve 2012 yıllarına ait VARK (Visual, Aural, Read-Write, Kinesthetic) envanteri aracılığıyla bireylerin görsel, işitsel, okuma/yazma ve kinestetik/dokunsal tercihlerini başarılı bir şekilde ölçümlemek mümkündür (Balakrishnana ve Woodsb, 2013, 165). Nitekim literatüre bakıldığında son dönemlerde pek çok araştırmada VARK öğrenme stili ölçeğinden yararlanıldığı görülmektedir (Wheeler, 2001; Puyleart, 2006; Hogan, 2009; Leite, Svinicki, ve Shi, 2010; Balakrishnana ve Woodsb, 2013).

Ayrıca literatürde VARK envanterinde yer alan ölçeğin, özellikle öğretimsel tercihleri içeren araştırmalar için iyi-uyumlu bir araç olarak nitelendirildiği görülmektedir (Fleming, 1995, 2001, 2010 ve 2012). Özellikle Fleming'in (2012) araştırmasında önerilen VARK envanteriyle öğretmenlerin baskın algısal tercihlerinin tespit edilmesi de mümkün hale gelmiştir (Fleming, 2012).

İngilizce VARK Öğrenme Stilleri Envanteri'nin geçerlilik ve güvenirlik çalışması Leite, W. L., Svinicki, M. ve Shi, Y. (2010) tarafından yapılmıştır. Ayrıca VARK Öğrenme Stilleri Envanteri'nin kullanımı için araştırmacı tarafından izin alınmıştır. Türkçeleştirilmiş VARK Öğrenme Stilleri Envanteri geçerlilik ve güvenirlik çalışması araştırmacı tarafından yapılıştır. 


\subsubsection{Kullanıcı ve Geriye Dönük İzleme Videoları}

Kullanıcı videoları göz izleme testi sonucunda elde edilen kullanıcı videoları, göz izleme testine katılan öğretmenlerin, 35-40 dakikalık ders anlatımı süresince göz izleme sistemi tarafından sesli ve görüntülü olarak gerçekleştirilen video kayıtlarıdır. Geriye dönük video kayıtları ise, teste katılanların genellikle algılarını anlamak ve değerlendirmek üzere kullanılan, göz izleme testi sonrasında üretilen video kayıtlarının kullanıcılara izlettirilerek yapılan video kayıtlarıdır.

\subsubsection{Yarı Yapılandırılmış Görüşme Formu}

Görüşme tekniğini kendi içinde yapılandırılmış, yarı yapılandırılmış ve yapılandırılmamış görüşmeler olarak sınıflamak mümkündür. Yarı yapılandırılmış görüşmede sorular önceden belirlenir ve bu sorularla veriler toplanmaya çalışılır (Gürbüz ve Şahin, 2015, 382-384). Literatüre uygun olarak, yapılan bu araştırmada nitel araștırma yöntemlerinden yarı yapılandırılmış mülakat tekniği kullanılmıștır. Bunun için öğretmenlerle gerçekleştirilen mülakat için yarı yapılandırılmış görüşme formu hazırlanmıştır. Yapılan literatür taraması çerçevesinde yarı yapılandırılmış görüşme formunu hazırlamak için öncelikle 2 sınıf öğretmeninin dersinde gözlem yapılmış ve göz teması ile ilgili davranışlar tespit edilmiştir. Daha sonra görüşme soruları hazırlanmış ve uzman görüşü alınmıștır. Hazırlanan görüşme soruları 50 öğretmene sorulmuş ve cevapları üzerinde içerik analizi yapılarak temalar belirlenmiştir. Temalar doğrultusunda yarı yapılandırılmış görüşme formu düzenlenmiş ve son şekli verilmiştir. Formda yer alan sorular çerçevesinde göz izleme testine katılan öğretmenlerle sesli görüşmeler yapılarak elde edilen ses kayıtları metne dökülmüş ve son aşamada ulaşılan veriler tezin amaç ve hedefleri doğrultusunda betimsel olarak yorumlanmıștır. Böylece göz izleme testine katılan öğretmenlerin göz teması davranışları hakkındaki görüşleri betimsel Çizelgeler eşliğinde incelenerek ulaşılan bulgular yorumlanmıştır.

\subsection{Veri Analizi}

Göz izleme verilerinin yorumlanması amacıyla SPSS istatistik yazılımı kullanılmıştır. Öğretmenin kıdemi, öğretmenin cinsiyeti, öğrencinin cinsiyeti, öğrencinin not ortalaması ve öğretmenin öğrenme stili bakımından öğretmenlerin öğrenciler üzerindeki odaklanma sayısı ve odaklanma süresinin farklılık oluşturması durumunu incelemek için MANOVA testi kullanılmıștır.

Kullanıcı ve geriye dönük izleme videoları ile yarı yapılandırılmış görüşme formu verileri öncelikle deşifre edilerek alt problemler doğrultusunda sinıflandırıldı. Ardından betimsel analiz yapılarak bulgulara ulaşıldı ve yorumlandı. Bu doğrultuda sonuçlar ve değerlendirme ortaya konuldu.

\section{Bulgular}

\subsection{Sınıf Öğretmenlerinin Derste Öğrencileriyle Göz Teması Kurma Davranışları ile Meslekî Kıdemlerine Yönelik Bulgular}

Göz izleme testine katılan öğretmen kıdemi, öğretmen cinsiyeti, öğrenci cinsiyeti, öğretmen algısal öğrenme stili ve öğrenci not ortalamasına göre odaklanma sayıları ve süreleri ile ilgili analiz yürütülmüştür. MANOVA sonuçlarına göre, öğretmen kıdemi, öğretmen öğrenme stilleri ve öğrenci not ortalaması bakımından odaklanma sayısı ve odaklanama süresinde farklılığa sebep olduğu saptanmıștır. Sonuçlar Çizelge 3'te gösterilmiştir. 
Çizelge 3: Göz İzleme Testine Katılan Öğretmenlerin Kıdemi, Cinsiyeti,

Öğrenci Cinsiyeti, Öğretmen Algısal Öğrenme Stili ve Öğrenci Not

Ortalamasına Göre Odaklanma Sayıları ve Süreleri ile İlgili Analiz

\begin{tabular}{|l|c|c|c|}
\hline & Pillai'sTrace Value & $\mathbf{F}$ & $\mathbf{p}$ \\
\hline Öğretmen Kıdem & 0,237 & 7,309 & $0,002^{\star \star}$ \\
\hline $\begin{array}{l}\text { Öğretmen Algısal } \\
\text { Ögrenme Stili }\end{array}$ & 0,580 & 4,903 & $0,000^{\star \star \star}$ \\
\hline $\begin{array}{l}\text { Öğrenci Not } \\
\text { Ortalaması }\end{array}$ & 1,706 & 1,859 & $0,000^{\star \star \star}$ \\
\hline${ }^{\star} \mathrm{P}<0,05 ;{ }^{* \star} \mathrm{P}<0,01 ;{ }^{* \star} \mathrm{P}<0,001$ & \multicolumn{3}{|l}{} \\
\hline
\end{tabular}

Kıdem değişkenine göre odaklanma süresi anlamlı olarak farklılaşmaktadır $(p=0,039)$ (Çizelge 4). Ancak, odaklanma sayısı kıdeme göre anlamlı bir farklılık göstermemektedir $(p=0,336)$. Başka bir anlatımla, sınıf öğretmenlerinin kıdemi arttıkça, odaklanma süresinin de artış gösterme eğiliminde olduğunu görmekteyiz anlamlı düzeyde etkileyen bir faktörken, odaklanma sayısını anlamlı düzeyde etkileyen bir faktör olmadığı söylenebilir. Öğretmen öğrenme stilleri değişkenine göre odaklanma süresi anlamlı olarak farklılaşmaktadır $(p=0,004)$. Ancak, odaklanma sayısı öğretmen öğrenme stillerine göre anlamlı bir farklılık göstermemektedir $(\mathrm{p}=0,199)$. Başka bir anlatımla, sınıf öğretmenlerinin öğrenme stilleri, odaklanma süresini anlamlı düzeyde etkileyen bir faktörken, odaklanma sayısını anlamlı düzeyde etkileyen bir faktör olmadığı söylenebilir. Öğrenci not ortalaması değişkenine göre odaklanma süresi $(p=0,031)$ ve odaklanma sayısı $(p=0,022)$ öğrenci not ortalamasına göre anlamlı bir farklılık göstermektedir. Başka bir anlatımla, öğrencilerin not ortalaması arttıkça, odaklanma süresini ve odaklanma sayısının da arttığı söylenebilir. (Bulgular Çizelge 4'te özetlenmiştir). 
Çizelge 4: Öğretmenlerin Kıdemi Ve Algısal Öğrenme Stilleri ve Öğrenci Not Ortalamaları ile Odaklanma Sayısı Arasındaki Illişkiler

\begin{tabular}{|l|l|c|c|c|c|c|}
\hline & $\begin{array}{l}\text { Bağımlı } \\
\text { Değişken }\end{array}$ & KT & sd & Ko & $\mathbf{F}$ & $\mathbf{p}$ \\
\hline \multirow{2}{*}{$\begin{array}{l}\text { Öğretmen } \\
\text { Kıdem }\end{array}$} & $\begin{array}{l}\text { Odaklanma } \\
\text { Sayısı }\end{array}$ & 2,642 & 1 & 2,642 & 0,944 & 0,336 \\
\cline { 2 - 7 } & $\begin{array}{l}\text { Odaklanma } \\
\text { Süresi }\end{array}$ & 3132,719 & 1 & 3132,719 & 4,494 & $0,039^{*}$ \\
\hline $\begin{array}{l}\text { Öğretmen } \\
\text { Algısal } \\
\text { Öğrenme Stili }\end{array}$ & $\begin{array}{l}\text { Odaklanma } \\
\text { Sayısı }\end{array}$ & 17,506 & 4 & 4,376 & 1,564 & 0,199 \\
\cline { 2 - 7 } & $\begin{array}{l}\text { Odaklanma } \\
\text { Süresi }\end{array}$ & 12160,289 & 4 & 3040,072 & 4,361 & $0,004^{\star *}$ \\
\hline \multirow{2}{*}{$\begin{array}{l}\text { Öğrenci Not } \\
\text { Ortalaması }\end{array}$} & $\begin{array}{l}\text { Odaklanma } \\
\text { Sayısı }\end{array}$ & 671,150 & 150 & 4,474 & 1,599 & $0,031^{*}$ \\
\cline { 2 - 7 } & $\begin{array}{l}\text { Odaklanma } \\
\text { Süresi }\end{array}$ & 173330,299 & 150 & 1155,535 & 1,658 & $0,022^{*}$ \\
\hline \multicolumn{7}{|l|}{${ }^{*}<<0,05 ;{ }^{* *} \mathrm{P}<0,01 ;{ }^{* \star *} \mathrm{P}<0,001$} \\
\hline
\end{tabular}

\section{Öğretmenlerin Kıdemlerine Göre Odaklanma Sayıları ve Süreleri}

Göz izleme testine katılan öğretmenlerin kıdemlerine göre odaklanma sayıları ve süreleri arasında anlamlı bir farklılaşma olup olmadığını saptamak için yürütülen istatistik analizlerinde, kıdem değişkenine göre odaklanma süresi anlamlı olarak farklılaşmaktadır $(p=0,039)$. Ancak, odaklanma sayısı kıdeme göre anlamlı bir farklılık göstermemektedir $(\mathrm{p}=0,336)$. Başka bir anlatımla, sınıf öğretmenlerinin kıdemi, odaklanma süresini anlamlı düzeyde etkileyen bir faktörken, odaklanma sayısının anlamlı düzeyde etkileyen bir faktör olmadığı söylenebilir.

\section{Öğretmenlerin Kıdemlerine Göre Sıklıkla ve Nadiren Göz Teması Kurduğu Öğrenciler ve Hiç Göz Teması Kurmadığı öğrenciler}

Araștırma kapsamında öğretmenlerin kıdemlerine göre sıklıkla ve nadiren göz teması kurma durumlarını analiz etmek için; her öğretmenin göz teması kurma sürelerinin aritmetik ortalamaları hesaplanmıştır. Daha sonra ortalamanın \%25 üstü ve \%25 altı ortalama aralık olarak belirlenip üst değerde kalan öğrenci sayısını sıklıkla, alt değerde kalan öğrenci sayısını nadiren göz teması kurulduğu öngörülmüştür. Sınıflardaki öğrenci sayılarının da değişiklik göstermesi sebebiyle öğretmenleri karşılaștırmak için yüzdelik değerler üretilmiştir. Elde edilen sonuçlara göre: odaklanma süresine göre kıdemli öğretmenlerin öğrencilerinin ortalama \%29,6'sı ile sıklıkla göz teması kurmasına rağmen kıdemsiz öğretmenlerin öğrencilerinin \%24,3'ü ile sıklıkla göz teması kurdukları, kıdemli öğretmenlerin öğrencilerinin \%39,9'u ile nadiren göz teması kurmalarına rağmen kıdemsiz öğretmenlerin öğrencilerinin \%46,2'si ile nadiren göz teması kurdukları görülmektedir. Bu bulguya göre odaklanma süresine göre kıdemli öğretmenlerin kıdemsiz öğretmenlere göre daha uzun sürelerde öğrencileri ile göz teması kurduklarını söylemek mümkündür. Ayrıca araştırmaya katılan öğretmenlerin hepsinin göz teması kurduğu, hiç göz teması kurmayan öğretmenin olmadığı görülmüștür.

\subsection{Sınıf Öğretmenlerinin Göz Teması Kurma Davranışına Yönelik Algısal Öğrenme Stillerine Ait Bulgular}

\section{Öğretmenlerin Algısal Öğrenme Stillerinin Belirlenmesi}

Uygulanan VARK Öğrenme Stilleri Envanterinde katılımcıların seçtiği cevaplara göre algısal öğrenme stiline ilişkin birer profil oluşturulmakta olup, her bir algısal öğrenme 
stilindeki rakamın büyüyerek, kullanma yüzdesinin artması, o algısal öğrenme stiline eğilimin arttığını göstermektedir. Bununla birlikte söz konusu profillerde küçük ve birbirine eşit rakamlar öne çıkan bir algısal tercihin olmadığını gösterirken, büyük ve eşit rakamlar ise öne çıkan birden çok algısal eğilimin olduğunu göstermektedir. $\mathrm{Bu}$ profillerde yer alan verilerden yararlanılarak hazırlanan Şekil 1'de göz izleme testine katılan tüm öğretmenlerin, öğretim ve öğrenme süreçlerinde kullandıkları algısal öğrenme stillerine ilişkin veriler gösterilmektedir.

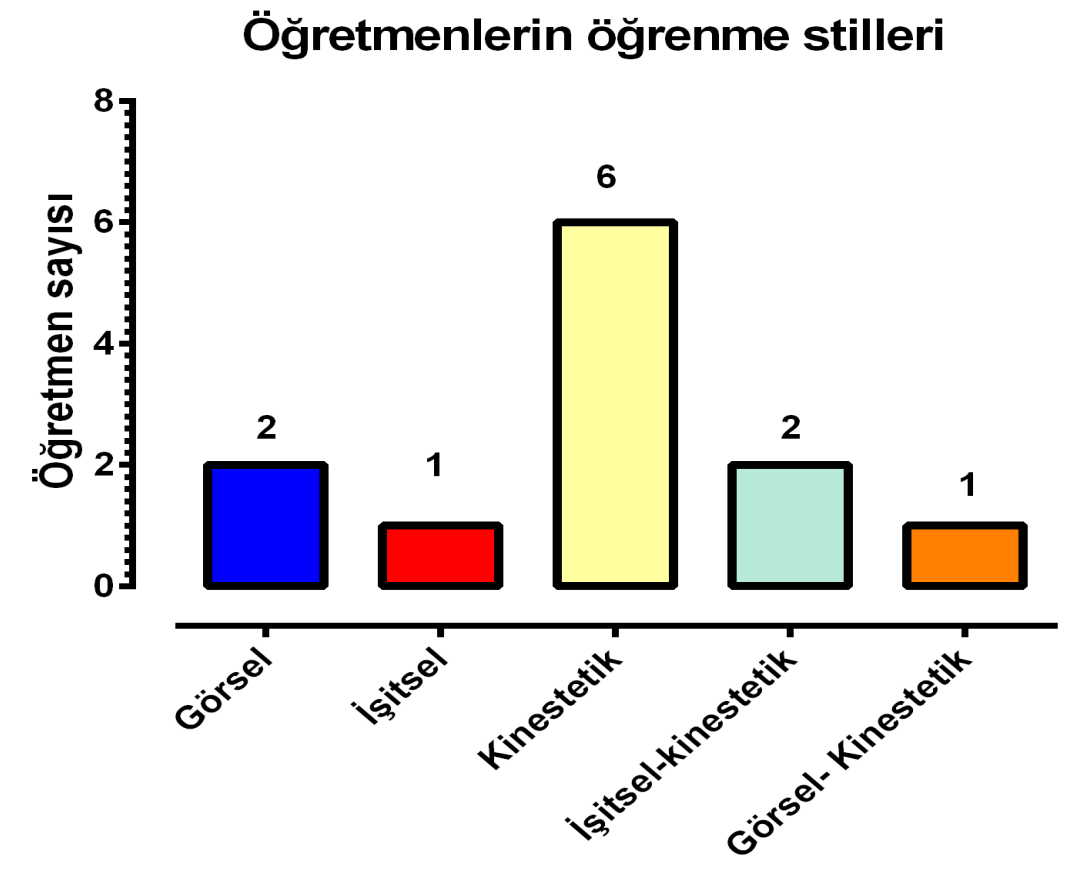

Şekil 1: Göz izleme testine katılan ögretmenlerin algısal ögrenme stilleri

Öğretmenlerin algısal öğrenme stillerinin yüzdelik dağılımı Şekil 2'de gösterilmiştir.

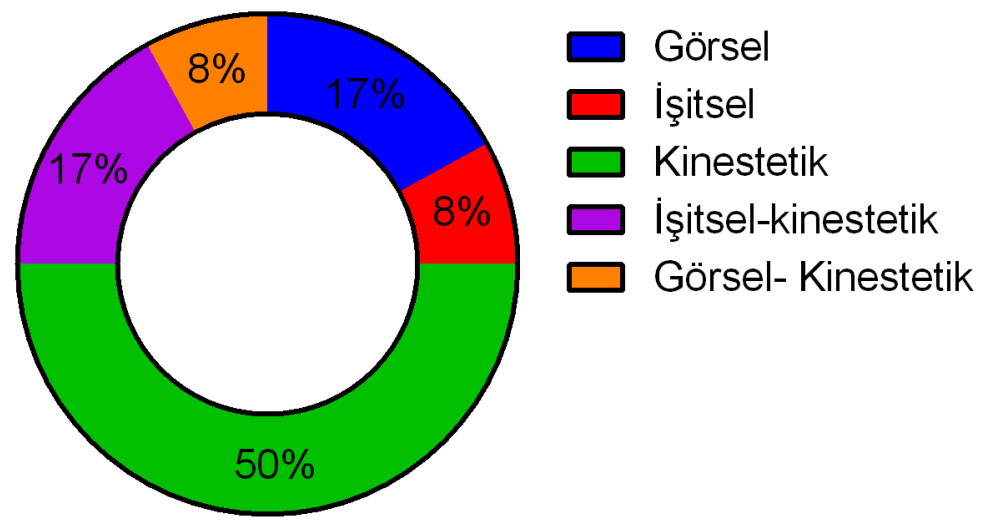

Şekil 2: Öğretmenlerin algısal öğrenme stillerinin yüzdelik dağılımı

\section{Öğretmenlerin Algısal Öğrenme Stillerine Göre Odaklanma Sayıları ve Süreleri}

Göz izleme testine katılan öğretmenlerin algısal öğrenme stillerine göre odaklanma süreleri ile ilgili analizde, öğrenme stillerinden hangisinin odaklanma süresi bakımından farklılık oluşturduğunu tespit etmek amacıyla MANOVA post-hoc testlerinden bonferroni testi yürütülmüştür (Çizelge 5). 
Çizelge 5: Öğretmenleri Öğrenme Stillerine Göre Odaklanma Süreleri

\begin{tabular}{|c|c|c|c|c|c|}
\hline & & & $\begin{array}{c}\text { Ortalamalar } \\
\text { Arası Fark }\end{array}$ & Std.Hata & $\mathbf{p}$ \\
\hline \multirow{20}{*}{$\begin{array}{l}\text { Odaklanma } \\
\text { Süresi }\end{array}$} & \multirow{4}{*}{ Görsel } & İşitsel & $-17,949$ & 7,465 & 0,201 \\
\hline & & Kinestetik & $-9,721$ & 4,787 & 0,478 \\
\hline & & İşitsel-Kinestetik & $-30,950$ & 5,538 & $0,000^{\star \star *}$ \\
\hline & & Görsel-Kinestetik & $-32,132$ & 8,173 & $0,003^{\star *}$ \\
\hline & \multirow{4}{*}{ İşitsel } & Görsel & 17,949 & 7,465 & 0,201 \\
\hline & & Kinestetik & 8,228 & 6,681 & 1,000 \\
\hline & & İşitsel-Kinestetik & $-13,001$ & 7,239 & 0,788 \\
\hline & & Görsel-Kinestetik & $-14,182$ & 9,409 & 1,000 \\
\hline & \multirow{4}{*}{ Kinestetik } & Görsel & 9,721 & 4,787 & 0,478 \\
\hline & & İşitsel & $-8,228$ & 6,681 & 1,000 \\
\hline & & İşitsel-Kinestetik & $-21,229$ & 4,425 & $0,000^{\star \star \star}$ \\
\hline & & Görsel-Kinestetik & $-22,411$ & 7,463 & $0,042^{*}$ \\
\hline & \multirow{4}{*}{$\begin{array}{l}\text { İşitsel- } \\
\text { Kinestetik }\end{array}$} & Görsel & 30,950 & 5,538 & 0,000 \\
\hline & & İşitsel & 13,001 & 7,239 & 0,788 \\
\hline & & Kinestetik & 21,229 & 4,425 & $0,000^{\star \star *}$ \\
\hline & & Görsel-Kinestetik & $-1,182$ & 7,966 & 1,000 \\
\hline & \multirow{4}{*}{$\begin{array}{l}\text { Görsel- } \\
\text { Kinestetik }\end{array}$} & Görsel & 32,132 & 8,173 & $0,003^{\star \star}$ \\
\hline & & İşitsel & 14,182 & 9,409 & 1,000 \\
\hline & & Kinestetik & 22,411 & 7,463 & $0,042^{*}$ \\
\hline & & İşitsel-Kinestetik & 1,182 & 7,966 & 1,000 \\
\hline
\end{tabular}

Sonuçlar incelendiğinde, görsel öğrenme stili görsel-kinestetik ve işitsel-kinestetik stillerine göre anlamlı derecede farklılık göstermektedir. Görsel-kinestetik ve işitselkinestetik stillerinde odaklanma süreleri ortalamaları görsel öğrenme stilindeki odaklanma süreleri ortalamalarına göre anlamlı derecede daha yüksektir. Ayrıca kinestetik öğrenme stili görsel-kinestetik ve işitsel-kinestetik stillerine göre anlamlı derecede farklılık göstermektedir. Görsel-kinestetik ve işitsel-kinestetik stillerinde odaklanma süreleri ortalamaları kinestetik öğrenme stilindeki odaklanma süreleri ortalamalarına göre anlamlı derecede dahayüksektir $\left({ }^{*} \mathrm{P}<0,05\right.$; ${ }^{* *} \mathrm{P}<0,01$; $\left.{ }^{* * *} \mathrm{P}<0,001\right)$.

Araștırma kapsamında son olarak öğrencilerin akademik başarı düzeylerine göre öğretmenlerin göz teması kurma davranışlarının değişip değişmediğini anlamak amacıyla, göz izleme testiyle elde edilen bulgulara odaklanma süreleri ve odaklanma sayılarına göre bakılmıştır. Araştırma kapsamında öğrencilerin akademik başarı düzeylerini tespit etmek üzere göz izleme testinin yapıldığı sınıflarda bulunan öğrencilerin Türkçe, Matematik, Hayat Bilgisi, Fen ve Teknoloji ile Sosyal Bilgiler derslerinin yılsonu not ortalamaları okul yönetimlerinden alınmıștır. Her bir öğrencinin bu derslere göre yılsonu başarı ortalaması hesaplanmıştır. Öncelikle öğrencilerin akademik başarıları ile öğretmenlerin göz teması kurma davranıșlarından odaklanma sayıları ve süreleri açısından bakılmış ve bu analiz sonucunda elde edilen bulgular Çizelge 6'da gösterilmiştir. 
Çizelge 6: Öğrenci başarısı ile göz teması arasındaki ilișki

\begin{tabular}{|c|c|c|c|c|}
\hline & & Odaklanma Sayısı & Odaklanma Süresi & Not Ortalaması \\
\hline \multirow{3}{*}{ Odaklanma Sayısı } & $r$ & 1 & 0,899 & 0,213 \\
\hline & $\mathrm{p}$ & & $0,000^{\star \star \star}$ & $0,001^{\star \star}$ \\
\hline & $\mathrm{N}$ & 242 & 242 & 242 \\
\hline \multirow{3}{*}{ Odaklanma Süresi } & r & & 1 & 0,209 \\
\hline & $p$ & & & $0,001^{\star \star}$ \\
\hline & $\mathrm{N}$ & & 242 & 242 \\
\hline \multirow{3}{*}{ Not Ortalaması } & $r$ & & & 1 \\
\hline & $\mathrm{p}$ & & & \\
\hline & $\mathrm{N}$ & & & 242 \\
\hline
\end{tabular}

\section{Tartışma}

Araştırma kapsamında, nicel ve nitel araştırma yöntemleri kullanılarak çeşitli veriler toplanmıștır. Araştırma kapsamında toplanan veriler analiz edildikten sonra ortaya çıkan bulgular yorumlanarak, öğretmenlerin göz teması kurma davranışlarını etkileyen faktörlerle ilgili, bilimsel yönden geçerliliği olan sonuçlara ulaşılmıştır.

Temel amacı öğretmenlerin öğrencileriyle göz teması kurma davranışlarını ve bu davranışları hakkındaki görüşlerini çeşitli değişkenlere göre tespit etmek olan araştırma sonuçlarını ve geliştirilen önerileri aşağıdaki başlıklar altında gruplandirmak mümkündür.

\section{1. Öğretmenlerin Kıdemleri ve Göz Teması Kurma Davranışları}

Araştırma sonucunda, sınıf öğretmenlerinin kıdem değişkeninin, öğrencileriyle olan göz teması kurma süresini anlamlı düzeyde etkileyen bir faktör olduğu ve kıdemli öğretmenlerin kıdemsiz öğretmenlere göre öğrencilerine daha uzun sürelerde odaklandığı tespit edilmiștir. Araștırmanın bu bulgusu literatürde yer alan farklı alanlarda yapılmış mesleki kıdeme göre göz teması kurma süre ve sıklığının farklılaştığını ortaya koyan Bahill ve LaRitz (1984), Malatesta ve Izard (1987), Günay (2003), Erol (2006) ve Williams ve Ward (2003) araştırmalarıyla benzeșmektedir. Ancak sıralanan araștırmalardan sadece Bahill ve LaRitz (1984) araştırmasında kıdemliler kıdemsizlere göre daha etkilidir sonucuna ulaşmıştır. Literatürde yer alan diğer araştırmaların sonuçlarına bakıldığında ise, mesleğinde kıdemsiz olan kişilerin göz teması sıklık ve sürelerinin kıdemlilerden daha üstün, daha uzun sürede veya daha fazla olduğu bulgusuna ulaşıldığı görülmektedir (Malatesta ve Izard, 1987; Günay, 2003; Erol, 2006; Williams ve Ward, 2003; Doğusoy, 2012). Özellikle Doğusoy (2012) tarafından göz izleme sistemi kullanılarak yapılan araştırma sonucunda kıdemsiz öğretmenlerin kavram haritası oluşturma süreçlerinde kıdemlilere göre daha farklı göz teması davranışlarını benimsedikleri ve kıdemsiz öğretmenlerin sürecin genelinde daha fazla odaklanma sayısına sahip oldukları belirtilmiştir (Doğusoy, 2012, 130).

Öte yandan yapılan bu araştırma sonucunda, kıdem değişkeninin öğretmenlerin öğrencileriyle kurdukları göz teması kurma davranışlarında odaklanma sayılarının herhangi bir etkisinin olmadığı da tespit edilmiştir. Ulaşılan bu bulgu literatürde yer alan ve gençlerle yaşlıları etkili iletişim performansı yönünden karşılaştıran Siegel ve Gregora (1985) araştırması ile benzerlik göstermektedir. Ayrıca Çubukçu ve Dündar (2003) tarafından öğretmenlerin sahip oldukları iletişim 
becerilerinin kıdemleriyle ilişkisinin olup olmadığını tespit etmeye yönelik yaptığı araştırma sonuçları ile benzeşmektedir. Her iki araştırma da benzer şekilde kıdem değişkeninin insanların göz teması kurma davranışlarıyla arasında herhangi bir ilişki olmadığını ortaya koymaktadır.

Bu çerçevede denilebilir ki,öğretmenlerin kıdemleriyle göz teması kurma davranışları arasında bir ilişki bulunmakla birlikte, öğretmenlerin kıdem değişkeni bu ilişkinin belirlenmesinde tek başına açıklayıcı bir değişken özelliği taşımamaktadır. Bunula birlikte kıdemli öğretmenlerin deneyimlerini ve tecrübelerini paylaşarak kıdemsiz öğretmenlerin göz teması kurma davranışlarında farkındalık kazanmaları, göz teması kurma süreleri ve sayılarını arttırmaları önem kazanmaktadır.

Ancak, çalışma grubundaki öğretmenlerin kıdem değişkeni ile göz teması kurma davranışı arasındaki ilişkiye yönelik görüşlerinde, öğretmenlerin büyük bir çoğunlukla (10 öğretmen) meslekî kıdemin öğrencileriyle göz teması kurma davranışlarını etkilediğini ve kıdemli öğretmenlerin kıdemsizlere göre öğrencilerle daha çokgöz teması kuracağını düşündüklerini ifade etmişlerdir. Daha açık bir ifadeyle öğretmen görüşlerine göre; meslekî kıdem göz teması kurma davranışlarında etkili ve açıklayıcı bir faktördür ve genellikle kıdemli öğretmenler kıdemsiz öğretmenlere göre çok daha fazla göz teması kurmaktadırlar.

Ayrıca araştırmanın nitel bulgularına göre; kıdemli öğretmenler ders anlatırken, öğrencilerin dersi dinleyip dinlemediğini gözlemlemek, sınıf ortamını bozan öğrencileri istenmeyen davranışlardan vazgeçirmek ve onları bazen sessizce uyarmak gibi nedenlerle sıklıkla göz teması kurduklarını düşünmektedirler. Kıdemsiz öğretmenler de benzer şekilde öğrencilerinin dersi anlayıp anlamadığını gözlemlemek, istenmedik davranışlardan onları vazgeçirmek, öğrencilerin derse dikkatlerini çekmek ve bazen onları uyarmak gibi amaçlarla öğrencileriyle göz teması kurduklarını düşünmektedirler. Dolayısıyla öğrencileriyle derste göz teması kuran öğretmenlerin mesleklerinde kazandıkları deneyimlerinin benzer amaçlarla göz teması kurma davranışlarını etkilediği söylenebilir.

\section{2. Öğretmenlerin Cinsiyetleri ve Göz Teması Kurma Davranışları}

Araştırma kapsamında öğretmenlerin cinsiyetlerine göre öğrencileriyle kurdukları göz teması davranışlarının değişip değişmediği tespit edilmeye çalışılmıştır. Ancak araştırma sonucunda görülmüştür ki, öğretmenlerin cinsiyetleri öğrencileri ile kurdukları göz teması davranışlarını etkilememektedir. Araştırmanın bu bulgusu öğretmen adaylarının iletişim becerisi algıları arasında cinsiyetlerine göre bir farklılık olmadığını ortaya koyan Pehlivan (2005), Bingöl ve Demir (2011), Dilekmen vd. (2008) ve Saracaloğlu vd. (2009) araştırmalarıyla benzeşmektedir.

Ancak ulaşılan bu bulgular literatürde yer alan ve insanların cinsiyetlerine göre sözsüz iletişim becerilerini kullanma düzeyleri arasında anlamlı farklılıklar olduğunu tespit eden pek çok araştırmayla farklıdır (Berglund vd., 2005; Deryakulu, 2006). Örneğin; Cunningham vd., (1997) araştırmasına göre kişilerarası iletişimde kadınlar erkeklere göre daha iyi; Şeker (2000) araștırmasında kadın öğretmenler erkek öğretmenlere göre daha etkili iletişim becerisine sahip ve Bozkurt (2003) araştırmasında, kadın öğretmenlerin erkek öğretmenlere göre iletişim becerisinin "etkililik" ve "yeterlilik" alt boyutlarında daha yüksek ortalamaya sahip olduğunu tespit etmişlerdir. Dolayısıyla denilebilir ki, araştırmanın bu bulgusu literatürde yer alan ve benzer konuda yapılan araştırmalarla farklılaşmaktadır. 
Ayrıca çalışma grubundaki öğretmenlerin göz teması kurma davranışları hakkındaki görüşlerine bakıldığında, kadın ve erkek öğretmenlerin tüm öğrencileriyle sıklıkla göz teması gerçekleştirdikleri, öğrencilerine ders anlatırken onları gözlemlemek, onları istenmedik davranışlardan vazgeçirmek, sınıf ortamını bozan öğrenciyi sessizce uyarmak ve bu sayede sorunu başlamadan çözebilmek için göz teması kurma davranışı gerçekleştirdikleri anlaşılmıştır.

Son olarak belirtilmelidir ki, ulaşılan tüm sonuçlar literatürde yer alan araştırmalarla birlikte değerlendirildiğinde öğretmenlerin cinsiyetlerinin derste öğrencileriyle göz teması kurma davranışları arasında farklılığa neden olmadığı, doğuştan gelen bu bireysel özelliğin öğretmenler açısından hiçbir şekilde bu iletişim becerisini geliştirme yönünden bir engel teşkil etmediği söylenebilir.

\section{3. Öğretmenlerin Algısal Öğrenme Stilleri ve Göz Teması Kurma Davranışları}

İkinci aşamada, yapılan analizler yardımıyla araștırmaya katılan öğretmenlerin algısal öğrenme stilleri değişkenine göre öğrencileriyle kurdukları göz teması kurma süre ve sıklıklarına bakılmıştır. Yapılan analizler sonucunda öğretmenlerin öğrenme stilleri değişkeninin sadece öğrencilerine odaklanma süresi itibariyle anlamlı farklılığa neden olduğu; buna karşılık öğrencilerine odaklanma sayısı itibariyle anlamlı düzeyde bir farklılık göstermediği tespit edilmiştir. Dolayısıyla denilebilir ki, öğretmenlerin sahip oldukları ve öğretim süreçlerinde kullandıkları algısal öğrenme stilleri ile öğrencileriyle göz teması kurma davranışları arasında, "odaklanma süresi” parametresi açısından anlamlı bir ilişki bulunmaktadır.

Üçüncü aşamada yapllan analizlerle öğretmenlerin öğrenme stillerinden hangisinin odaklanma süresi bakımından farklılık yarattığı tespit edilmeye çalışılmıştır. Ulașılan bulgulara göre görsel öğrenme stili görsel-kinestetik ve ișitsel-kinestetik stillerine göre anlamlı derecede farklılık göstermektedir. Yine görsel-kinestetik ve işitsel-kinestetik stillerinde odaklanma süreleri ortalamaları görsel öğrenme stilindeki odaklanma süreleri ortalamalarına göre anlamlı derecede daha yüksek olduğu araştırma sonucunda tespit edilmiștir. Bu bulgular Gilakjani (2012), Hawk ve Shah (2007), Leite, Svinicki ve Shi (2010) ve Fleming (2012) araștırmaları ile benzerlik göstermektedir.

Ayrıca kinestetik öğrenme stili görsel-kinestetik ve işitsel-kinestetik stillerine göre anlamlı derecede farklılık gösterirken, görsel-kinestetik ve işitsel-kinestetik stillerinde odaklanma süreleri ortalamaları kinestetik öğrenme stilindeki odaklanma süreleri ortalamalarına göre anlamlı derecede daha yüksek olduğu da tespit edilmiştir. Ulaşılan bu bulgular literatürde yer alan Adler (2015), Pektaş (1998) ve Güven (2004) araştırmalarıyla uyumludur.

Son olarak öğretmenlerin algısal öğrenme stillerine göre göz teması kurma davranışları hakkındaki görüşlerine bakılmıştır. $\mathrm{Bu}$ çerçevede denilebilir ki, kinestetik öğretmenlerle işitsel öğretmenlerin hepsi oldukça sıklıkla, tüm öğrencileriyle, cinsiyet ayrımı yapmadan göz teması kurduklarını düşünmektedirler. Ayrıca kinestetik öğretmenler de olduğu gibi işitsel ve görsel öğretmenler de benzer şekilde sınıf ortamında istenmedik davranışa kalan öğrencileri uyarmak ve ders anlatırken etkinliği sağlamak üzere göz teması davranışı kurmaktadırlar.

Bununla birlikte başarılı öğrencilerle göz teması kurma sıklıkları ve süreleri konusunda gerek işitsel gerekse dokunsal öğretmenlerin her biri farklı 
düşünmektedir. Bu durum söz konusu davranışta algısal tercihlerin çok etkili olmadığını göstermektedir.

Genel bir değerlendirme yapıldığında kinestetik tercihleri baskın olan öğretmenlere göre görsel ve işitsel öğretmenlerin göz teması kurma davranışları konusunda daha pasif olduklarını düşündüklerini ve bu davranışları hakkında kinestetik öğretmenlere göre çok kesin değerlendirmeler yapmaktan kaçındıkları söylenebilir.

\section{4. Öğrencilerin Cinsiyetleri ve Öğretmenlerin Göz Teması Kurma Davranışları}

Göz hareketleri araştırma kapsamında ölçümlenmeyen, ancak bizzat kendileri de göz teması kurma davranışı geliștirebilen öğrencilerin sahip oldukları cinsiyetlerine göre, öğretmenlerin onlarla kurdukları göz teması kurma davranışlarının süre ve sayı yönünden değişip değişmediğine bakılmıştır.

Araştırma sonucunda öğretmenlerin göz teması kurma davranışlarında, öğrencilerin cinsiyetleri ile odaklanma süresi ve sayısı arasında anlamlı bir ilişki olmadığı görülmüştür. Nitekim yapılan literatür taramasında da öğrencilerin cinsiyetleri ile öğretmenlerin sözsüz iletişim becerileri arasındaki ilişkiyi konu edinen araştırmalara yer verilmediği görülmüștür. Ancak Bacanll, (2015), sözsüz iletişimin sözlü iletişime göre daha çok duygusal mesajların iletiminde kullanılmasından hareketle, öğretmenlerin kız öğrencilerle erkek öğrencilere göre daha fazla göz teması kurabileceğini belirtmektedir (Bacanlı, 2015, 46). Öner (1999) ise araştırmasının sonucunda, öğretmenlerin kız öğrencilere daha sabırlı, güler yüzlü olduğu, onların soru sormasını daha çok istediği ve sınıfta yapılan şakaların kız öğrenciler tarafından daha olumlu algılandığını ortaya koymuştur.

Araştırmanınbulguları literatürdeyeralan butespitlerlebirliktedeğerlendirildiğinde; öğretmenlerin göz teması kurma davranışları üzerinde gerek kendi cinsiyetlerinin, gerekseöğrencilerin cinsiyetlerininbelirleyicibiretkisibulunmadığınıgöstermektedir. Nitekim öğretmenlerin kendi göz teması kurma davranıșları hakkındaki görüşlerine bakıldığında, hem kadın hem erkek öğretmenlerin çoğunlukla (12 öğretmenden 8 tanesine göre), kendilerinin ve öğrencilerinin cinsiyetlerinin onlarla kurdukları göz teması davranışını etkileyen bir değişken olmadığını söyledikleri görülmektedir. Bu konuda aksini düşünen ve azınlıkta kalan öğretmenlerden 3 tanesi "Erkeklere daha çok" buna karşılık bir tanesi "Kızlara daha çok" göz teması kurma davranışı gösterdiklerini düşünmektedirler.

Son olarak öğretmenlerin bu konudaki görüşlerine bakıldığında, öğrencilerin cinsiyetlerine göre göz teması kurma davranışlarının değișeceğini düșünen öğretmenlerin genellikle bu durumu çocukların doğuştan gelen özellikleriyle açıklamaya çalıştıkları, özellikle erkeklerin daha hareketli, daha dikkatsiz ve ilgisiz olduğunu düșünerek ya onlara daha fazla bakmak ya da daha az bakmak durumda kaldıklarını söyledikleri görülmüştür. Yine bir başka öğretmen kız çocuklarının kendisini etkili dinlediği için, erkek öğrencilerin ise daha çok hareketli olduğu için bakış sıklığını dengelediğini söylemektedir.

Öğretmenlerin hiç biri kendi cinsiyetlerine göre bir ayrımı ya da görme davranışı değişikliğinin olduğunu kabul etmemektedirler. Yani erkek öğretmenler "ben kız çocuklarını daha çok severim" ya da kadın öğretmenler "ben erkek çocuklarını daha çok sevdiğim için onlarla daha fazla gözlerimle temas kurarım" şeklinde düșünce beyan etmedikleri araștırma sonucunda görülmüștür. Ayrıca bu konuda 
görüşleri sorulan öğretmenlerin bir kısmı öğrencilerin cinsiyetlerine göre bakış sıklıklarının fark etmesini bile anormal bir durum olarak değerlendirdikleri, kesinlikle bilinçli olarak bu davranışlarının öğrenci cinsiyetlerine göre değișmeyeceğini belirttikleri görülmüștür.

Sonuçolaraköğretmenlerinöğrencilerin cinsiyetfarklılıklarına göre gözteması kurma davranışları hakkındaki görüşlerinin değiştiğini, fakat bu durumun öğretmenlerin kız ve erkek öğrencilerin davranışlarıyla ilgili geliştirdikleri genel kanatlarından kaynaklandığı söylenebilir. Aslında bu durumda bile öğretmenin erkek öğrenciye daha sık bakmasına neden olan davranış yargısı, bir başka öğretmenin kız ya da erkek öğrenciye daha az bakma nedeni sayılmaktadır. Dolayısıyla öğretmenlerin kız ve erkek öğrencilerin sınıftaki hal ve davranışlarıyla ilgili genel görüşlerinin onlara yönelik göz teması kurma davranışları hakkındaki düşüncelerini şekillendirdiği söylenebilir. Ancak esasında göz teması kurma davranışlarını değiștirmedikleri araştırma sonucunda ortaya çıkmaktadır.

\section{5. Öğrencilerin Başarı Düzeyleri ve Öğretmenlerin Göz Teması Kurma Davranışları}

Araştırma kapsamında öğrencilerin akademik başarı düzeylerine göre öğretmenlerin göz teması kurma davranışlarının değișip değişmediğini anlamak amacıyla, göz izleme testiyle elde edilen bulgular öğrencilerin akademik başarılarına göre yorumlanmıştır.

Araştırma sonucunda, öğrencilerin başarı düzeyi değişkeninin öğretmenlerin öğrencilerine yönelik derste gerçekleştirdikleri göz teması kurma davranışlarını odaklanma süresine ve odaklanma sayısına göre anlamlı düzeyde etki ettiği görülmektedir. Araştırma sonucunda ulașılan bulgular öğretmenlerin akademik yönden bașarılı öğrencilerle, başarısız öğrencilere göre daha uzun sürelerde ve sıklıklarda göz teması davranışı geliştirdiklerini göstermektedir. Dolayısıyla denilebilir ki, gerek odaklanma sıklıkları gerekse odaklanma süreleri itibariyle, öğretmenlerin öğrencileriyle kurdukları göz teması davranışları ile öğrencilerin akademik başarı düzeyi arasında doğru orantılı bir ilişki bulunmaktadır.

$\mathrm{Bu}$ bulguya benzer șekilde öğretmenlerin bu konudaki görüşlerine bakıldığında, öğretmenlerin büyük çoğunluğunun (11 Öğretmen) derste öğrencileriyle gerçekleștirdikleri göz teması kurma davranışları ile öğrencilerin akademik başarı düzeyleri arasında ilişki ve etkileşimi olduğunu düşündüğü görülmektedir.

$\mathrm{Bu}$ bulgu, öğretmenlere göre öğrencilerin çalışkan ve akademik yönden başarılı ya da aynı yönlerden başarısız olmasına bağlı olarak onlarla derste kurdukları göz teması kurma davranışlarının sıklık ve süreleri değişmektedir. Ancak ilginçtir ki, bu görüşe sahip öğretmenlerden 5 tanesine göre öğretmenler genellikle "Başarısız öğrencilerle daha sık" göz teması kurarken, 6 tanesine göre öğretmenler genellikle "Başarılı öğrencilerle daha sık" göz teması kurmaktadır.

Ayrıca araştırma sonucunda sadece 12 öğretmenle röportaj yapılmasına ve bunlardan sadece 11 tanesinin bu faktöre göre göz teması kurma davranışının değiştiğini söylemesine rağmen bu değişimi açılklama ve anlamlandırma konusunda öğretmenlerin yüzlerce cümle kurduğu görülmüştür. Bu açıklamalarında öğretmenler özetle, ya başarısız öğrencinin kendisini dinlemediği oysa başarılı öğrencinin derse daha sık katıldığından bahisle ona daha sık ve daha uzun süre baktığını ya da dersi anlamayan öğrencilerin başka bir şeyle ilgilenmesi nedeniyle onla sıklıkla göz teması 
kurduğunu beyan ettiği görülmüştür. Ancak 11 öğretmenin akademik başarıya bağlı olarak öğrencileriyle göz teması kurma sıklık ve süresinin değiștiğini kendine göre açıklayan cümlelerin pratik hayatta önemli bir yeri ve gerçekliği olduğu söylenebilir.

Öte yandan araştırma kapsamında sınıf öğretmenlerinin öğrencilerle göz teması kurma süre ve sayılarıyla, öğrencilerin akademik başarı düzeyleri arasındaki ilişki olup olmadığı da incelenmiştir. Bu amaçla yapılan analizler sonucunda ulaşılan bulgular göstermiştir ki sınıf öğretmenlerinin öğrencileriyle göz teması kurma süresi ve sıklığıyla, öğrencilerin akademik başarı düzeyleri arasında düşük düzeyde, ancak pozitif ve anlamlı ilişki bulunmaktadır. Araștırmanın bu bulgusu, öğretmenlerin derste öğrencileriyle kurdukları göz temasının sayısı ve süresinin artmasının, öğrencilerin akademik yönden başarılarını da arttırdığını ortaya çıkartmaktadır. Ayrıca literatürde yer alan ve aynı konuda yapılan bazı araştırmalar tezin bu bulgusunu doğrular niteliktedir (Özer, 2015; Aydın, 2013; Kisaç, 2004; Good ve Bprohy, 2006).

Öyleyse denilebilir ki, öğretmenler ders anlatırken göz teması kurma gibi sözsüz iletişim becerilerini etkili kullandıkları takdirde bu durumdan öğrencilerin akademik başarıları olumlu yönde etkilenecektir. Dolayısıyla öğretim mesleğinde başarılı olmak ve aynı zamanda sınıflarındaki tüm öğrencilerin derslerinde başarılı olmasını isteyen öğretmenler onlarla sıklıkla göz teması kurmalıdırlar.

\section{6. Öğretmenlerin Göz Teması Kurma Davranışları Hakkındaki Genel Görüşleri}

Araştırma kapsamında son olarak göz izleme testine katılan öğretmenlerin gerek göz izleme testindeki, gerekse genel öğretim süreçlerindeki göz teması kurma davranışları hakkındaki görüşleri değerlendirilmiş ve ulaşılan görüşler aşağıda kısaca anlatılmıştır.

Araştırma sonucunda öğretmenlerin; isteklendirme, sınıf yönetimi, disiplin ve sözsüz iletişim başlıkları altında göz teması kurdukları görülmektedir.

$\mathrm{Bu}$ başlıklar altında toplanan göz teması kurma amaçlarına bakıldığında, öğretmenlerin öğretim süreçlerinde öğrencilerinin ilgisini ve dikkatini derse çekmek, aralarındaki sevgi ve saygıya dayalı ilişkiyi güçlendirmek, hata yapanları uyarmak, öğretim sürecini etkilemeden mesaj vermek, konuyu ya da anlattıklarını anlayıp anlamadığına ilişkin geri dönüt almak amacıyla göz teması davranışı gerçekleştirdikleri anlaşılmaktadır.

Özellikle öğretmenlerin kendi his ve duygularını öğrencilere samimi bir şekilde anlatmak, benzer şekilde öğrencilerin de içinden geçen düşünce ve hisleri anlamlandırabilmek amacıyla onlarla sıklıkla göz teması kurdukları araştırma sonucundan anlaşılmaktadır. Ayrıca öğretmenlerin ders anlatımındaki sözlü iletişimlerini güçlendirmek, jest ve mimiklerle destekledikleri sözlü mesajlarını daha da kuvvetlendirmek, öğrencilerinden gelen benzer sözsüz mesajların kodlarını çözmek amacıyla da onlarla sıklıkla göz teması kurdukları anlaşılmaktadır.

Yine öğretmenlerin, öğrencileriyle kurdukları göz teması kurma davranışlarının önemli bir kısmı da sınıfta disiplini sağlamak, otoritelerini güçlendirmek ve önceden belirlenen kurallara göre dersin işlenmesini sağlamak amacıyla olduğu araştırma sonucunda anlaşılmaktadır. Böylece öğretmenler göz teması kurma davranışlarıyla öğrencilerini sınıf kurallarına uymaya, istenmedik davranışlarına 
sessizce son vermeye ve kendisini dinlemeye yöneltmek amacıyla onlarla göz teması kurdukları görülmüştür.

Öğretmenlerin görüşleri doğrultusunda; öğrencilerin ilgi ve dikkatlerine, dersin konu, içerik ve etkililiğine, sınıfta sorunlu öğrencilerin bulunmasına, öğrencilerin hareketli, sessiz veya içine kapanık olmasına göre, onlarla kurdukları göz teması kurma davranışlarındaki süre ve sıklıkların değișebildiği düşünülmektedir. Öğretmenlerin bir kısmı ders anlattığı sınıf mevcudunun az ya da çok olması veya sınıfta öğrencilerin oturuş düzenin de göz teması kurma davranışını önemli düzeyde etkilediğini düşünmektedirler.

Araştırmaya katılan öğretmenlere göre derste öğrencilerle etkili bir şekilde göz teması kurmak hem sınıfın geneli hem de öğrencilerin her birisi için akademik başarının en temel belirleyicisidir. Bu stratejik rol ve önemin yanı sıra öğretmenler, öğrencilerin kendilerine olan özgüvenin arttırılmasında, dersin ve öğretmenin sevilmesinde, öğrencilerinin derse ve konuya odaklanmasının sağlanmasında göz teması kurma davranışının oldukça yararlı ve etkili olduğu görüşünü paylaşmaktadırlar.

\section{Sonuç ve Öneriler}

Araştırma kapsamında, nicel ve nitel araştırma yöntemleri kullanılarak çeşitli veriler toplanmıștır. Araştırma kapsamında toplanan veriler analiz edildikten sonra ortaya çıkan bulgular yorumlanarak, öğretmenlerin göz teması kurma davranışlarını etkileyen faktörlerle ilgili, bilimsel yönden geçerliliği olan sonuçlara ulaşılmıştır. Kıdem değişkenine göre odaklanma süresi anlamlı olarak farklılaşmaktadır $(\mathrm{p}=0,039)$. Ancak, odaklanma sayısı kıdeme göre anlamlı bir farklılık göstermemektedir ( $\mathrm{p}=0,336)$. Başka bir anlatımla, sınıf öğretmenlerinin kıdemi, odaklanma süresini anlamlı düzeyde etkileyen bir faktörken, odaklanma sayısını anlamlı düzeyde etkileyen bir faktör olmadığı söylenebilir. Öğretmenlerin öğrenme stilleri değişkenine göre odaklanma süresi anlamlı olarak farklılaşmaktadır $(p=0,004)$. Ancak, odaklanma sayısı öğretmenlerin öğrenme stillerine göre anlamlı bir farklılık göstermemektedir ( $p=0,199)$. Öğrenci odaklanma süresi $(p=0,031)$ ve odaklanma sayısı $(p=0,022)$ öğrenci not ortalaması değişkenine göre anlamlı bir farklılık göstermektedir. Son olarak araştırma sonucunda elde edilen bulgulara göre öğretmenlerin büyük çoğunluğunun derste öğrencileriyle gerçekleştirdikleri göz teması kurma davranışları ile öğrencilerin akademik başarı düzeyleri arasında ilişki ve etkileşimi olduğu düşünülmektedir.

Temel amacı öğretmenlerin öğrencileriyle göz teması kurma davranışlarını ve bu davranışları hakkındaki görüşlerini çeşitli değişkenlere göre tespit etmek olan araştırma sonuçlarını ve geliştirilen önerileri aşağıdaki başlıklar altında gruplandırmak mümkündür.

\section{Öğretmenlerin Göz Teması Kurma Davranışlarına Yönelik Öneriler}

Araştırma sonucunda ulaşılan bulgulara göre öğretmenlerin öğrencileriyle göz teması davranışlarını geliştirmek amacıyla bazı önerilerde bulunmak mümkündür. $\mathrm{Bu}$ öneriler aşağıda maddeler halinde sıralanmıştır.

- Göz teması kurma davranışlarının özellikle öğretim süreçlerinde anlam ve öneminin farkında olan öğretmenler ilk olarak basit bireysel gözlemleme teknikleriyle, sene başından itibaren sıklıkla, hangi sürelerle, hangi sebep ve amaçlarla öğrencileriyle göz teması kurduklarını belirlemesi gerekmektedir. 
Öğretmenlerin zaman zaman yapacakları bu gözlemlerle elde edeceği bulgular bir sonraki derste onu daha etkili göz teması kurma davranışına yöneltecektir.

- Öğretmenler hem kendilerinin hem de her bir öğrencinin algısal öğrenme tercihini tespit etmeli ve bu tercihlere göre göz teması kurma davranışını yönetmeye çalışmalıdır. Ayrıca bu araştırmada kullanılan yöntem dışında, görsel, işitsel ve kinestetik öğretmen-öğrenci profillerinin sınıf ortamlarında hareket tarzlarını bilmek suretiyle, hem kendisinin hem de öğrencilerin algısal öğrenme tercihleri hakkında görüş sahibi olması öğretim sürecini etkinleștirecektir. Bu sayede farklı öğrenme stillerine sahip öğrencilerin de dikkatini daha rahat öğrenme sürecine dahil edebilecektir.

- Meslekî kıdem açısından bakıldığında kıdemli öğretmenlerin göz teması kurma davranışlarını kıdemsiz öğretmenlere göre daha fazla kullandıkları dolayısıyla öğrencilerin daha başarılı oldukları araștırma sonuçlarından çıkarılabilir. $\mathrm{Bu}$ durumda mesleğe yeni başlamış veya kıdemsiz öğretmenlerin bu konuda farkındalık oluşturmaları sağlanmalıdır. Kıdemli öğretmenlerin kıdemsiz öğretmenlere mentorluk yaparak göz teması kurma davranışını geliştirme yönünde çalışmalar yapması yerinde olacaktır.

- Öğretmenlerin göz teması kurma davranışlarının öğrencilerin başarılarını arttırdığı, başarılı öğrencilerle ise daha fazla göz teması kurulduğu araştırma sonucunda ortaya çıkmaktadır. Bu durumda öğretmenlerin başarısı düşük öğrenciler ile de göz teması kurarak başarılarını arttıracakları konusunda farkındalık oluşturulması ve bu konuda teşvik edilmesi sağlanmalıdır. Zira başarının bu yöntemlerle arttığını farkeden öğretmenler göz teması kurma davranışını pekiştireceklerdir. Bunun devamında da başarının artması sağlanacaktır.

\section{Gelecekte YapıIması Planlanan Araştırmalara Yönelik Öneriler}

Araştırmanın özgün yanını oluşturan göz izleme sistemlerinin kullanılması konusunda bundan sonra yapılacak araştırmalara yol gösterici olması bu araştırmanın önemini oluşturan unsurlardan biridir. Dünyada ve ülkemizde göz izleme sistemleri kullanılarak gerçek sınıf ortamında gerçekleştirilmiş araştırmalara rastlanmamıştır. Bu açıdan bakıldığında bundan sonra bu alanda yapılacak araştırmalara bazı öneriler sunmak yerinde olacaktır.

- Göz izleme araştırmalarının maliyetleri düşmekle birlikte kullanım koşulları kolaylaşmış olsa da özellikle mobil göz izleme sistemlerinin temini, kiralanması ve kullanılması açısından büyük maddi problemler bulunmaktadır. Kısıtlı sürelerle ödünç alınan ya da kiralanan sistemlerle çok fazla sayıda katılımcının yer aldığı bu tarz araştırmalar yapmak mümkün olmamaktadır. Özellikle bu araştırmaya pasif değişkenler olarak katılan, bu yüzden göz hareketleri ölçümlenmeyen öğrencilerin de göz hareketlerinin tespit edilmesi, araștırmaya 12 öğretmen yerine daha farklı okullarda ve dönemlerde görev yapan 100'ün üzerinde öğretmenin katılımının sağlanması genellenebilir sonuçlara ulaşılmasını sağlayacaktır.

- Araştırma öncesinde birkaç defa öğretmenlere bu teknoloji hakkında teorik tanıtımlar yapılmasına rağmen gözlem için uygulamaya başlanıldığında bazı sorunların yaşanması kaçınılmaz olmuştur. Örneğin; gözlüğün ölçümleme ayarlarının yapılması, öğretmenin gözlüğe, öğrencileri ise gözlüklü öğretmene alışması bazı sınıflarda 5-10 dakika bazı sınıflarda 15-20 dakikalık aksamalara neden olmuştur. Göz izleme sisteminin kullanımı için ön testlerin yapılması, yedek 
pil ve hafıza kartı bulundurulması, öğretmenlerin sözlü ve görsel anlatımlarla bilgilendirilmesi test sürecini hızlandıracaktır. Ayrıca bu işlemlerin yapılması için yardımcı bir araştırmacının bulunması zaman tasarrufunu ve veri güvenliğini arttıracaktır.

- Göz izleme cihazı ile kaydedilen görüntülerin test süresinin ardından öğretmenlere izlettirilip yorumların yapılması nitel verilerin daha sağlıklı ortaya çıkmasını sağlayacaktır. Fakat göz izleme cihazının kullanımından kaynaklanan zaman ve depolama problemlerinden ötürü bu uygulamayı hemen gerçekleştirmek güçleşmektedir. Yardımcı araştırmacı ve yedek hafıza kartları ile bu durumun önüne geçilebilmektedir.

- Öğretmenlerin kameraya kaydedilmesi, ders anlatırken izlendiğinin ve gözlendiğinin bilincinde olması gibi etkenlerin önüne geçmek adına bir senelik dönemde belirlenen günlerde öğretmenin bu uygulamayı kendi isteğiyle ve öğrencilerini alıștırarak sürekli yapması daha güvenilir bulgulara ulaşılmasını sağlayacaktır.

- Göz izleme sistemlerindeki teknolojik gelişmelerle küçültülmüş, yüksek kalite görüntü kaydı yapan, taşıma kolaylığı bulunan, anlık uzaktan izleme sistemlerini içerisinde barındıran gelişmiş gözlük sistemlerini kullanarak araştırma esnasında karşılaşılan sınırlılıkları azaltmak mümkündür.

- Araştırma kapsamında temelde dört değişken üzerine odaklanılmıştır. Öğretmenlerin görüşlerinde de belirttiği üzere sınıf yerleşim planı, oturma düzeni, öğrencilere anlatılan dersin ve konunun içerikleri, ders materyalleri vb. farklı değişkenlerin öğrencilerin ve öğretmenlerin göz hareketleri birlikte ölçümlenerek yapılan araştırmalarla bu konuda önemli farkındalık yaratacak nitelikte görüşlere ulaşmanın mümkün olabileceği değerlendirilmektedir.

- Son olarak belirtilmelidir ki, literatürde yer alan binlerce göz izleme araştırmasında görüldügü üzere, bu tarz araștırmalar genellikle cansız bir tane objeye (kapı, kabin kokpit Web sayfası, resim vb.), kısa sürelerde (1 veya 5 dakika) ve basit kullanıcı tercihlerini (beğenme ya da beğenmeme gibi) tespit etmek üzere yapılmaktadır. Oysa bu araştırmada göz hareketleri ve göz teması kurma davranışları, birden çok canlı objeye odaklanarak, yaklaşık 70 dakikalık sürelerle ve katılımcılar ayakta konuşurken ölçümlenmeye çalışılmıştır.

Sözün özü, bu araştırma kendi alanında ve kendi konusunda pek çok açıdan bir ilk niteliği taşımakta olup, bu nedenle araştırma sonucunda ulaşılan kısıtlı bulgular bile gelecekte yapılacak benzer araştırmalara büyük ufuklar açacağı değerlendirilmektedir.

\section{Kaynaklar}

Adler, A. (2015). İnsan Tabiatını Tanıma. 12.Baskı, (A. Yörükhan, Çev.). Ankara: İş Bankası.

Akpınar, R. B. (2006). Duygusal yüz ifadelerini anlama becerisini geliștirmeye yönelik örnek bir öğretim programı. Journal of Human Sciences, 1(1). 1-10

Aydın, A. (2013). Sinıf yönetimi. İstanbul: Pegem Akademi.

Bacanlı, H. (2015). Eğitim Psikolojisi. 22.Baskı, İstanbul: Pegem Akademi.

Bahill, A.T ve LaRitz, T. (1984). Why can't batters keep their eyes on the ball? American Scientist, 72(3), 249-253. 
Balakrishnana, B.ve Woodsb, P.C., (2013). A comparative study on real laband simulation lab in communication engineering from students' perspectives. European Journal of Engineering Education, 38(2), 159-171.

Baltaş, Z. ve Baltaş, A. (2015). Bedenin Dili. (33. Basım), İstanbul: Remzi.

Berglund, E., Eriksson, M. ve Westerlund, M. (2005). Communicative skills in relation to gender, birth order, child care and socio economic status in 18-month-old children.Scandinavian Journal of Psychology, December, 46(6), 485-491.

Bingöl G. ve Demir A. (2011). Amasya sağlık yüksekokulu öğrencilerinin iletişim becerileri. Göztepe Tıp Dergisi 26(4):152-159.

Bozkurt, N., (2003). İlköğretim sınıf öğretmenlerin iletiși becerilerine ilișkin algılarının çeşitli değişkenler açısından incelenmesi. Yüksek Lisans Tezi, Dokuz Eylül Üniversitesi Buca Eğitim Fakültesi Eğitim Bilimleri Bölümü, İzmir.

Cüceloğlu, D. (2015). İnsan ve davranışı. Remzi Kitabevi.

Çubukçu Z., ve Dündar, İ. (2003). Okul yöneticilerinin iletişim becerilerine ilişkin ögretmenlerin algı ve beklentileri. Ankara: Milli Eğitim Yayınları

Çuhadar C., Özgür H., Akgün F., Gündüz Ş. (2014). Öğretmen adaylarının iletişim becerileri ve iletişimci biçimleri. Ahi Evran Üniversitesi Kırşehir Eğitim Fakültesi Dergisi (KEFAD) 15(1), 295-311.

Deniz, K. (2013). Eğitimde etkili iletişim. A. Güzel, H. Karatay (Ed.). Türkçe öğretimi el kitab1. (s. 521-570). Ankara: Pegem Akademi.

Deniz, K. (2015a). Türkçe öğretmen adaylarının etkili iletişim dersine yönelik beklentileri. Ana Dili Ĕgitimi Dergisi, 3(2), s.63-80.

Deniz, K. (2015b). Türkçe öğretmeni mi iletişim ĕgitmeni mi? D. Uçgun, A. Balcı (Ed.). Akademik hayatının 25.yılında Türkçe eğitimi alanının ilk profesörü Murat Özbay’a armağan. (s. 449-462). Ankara: Pegem Akademi.

Deryakulu, D. (2006). Bireysel farklılıklar ve eğitime yansımaları. Y. Kuzgun ve D. Deryakulu (Ed.), Eğitimde Bireysel Farklılıklar içinde, Ankara: Nobel.

Dilekmen, M., Başçı, Z., ve Bektaş, F. (2008). Eğitim Fakültesi Öğrencilerinin İletişim Becerileri. Atatürk Üniversitesi Sosyal Bilimler Enstitüsü Dergisi,12(2).

Doğusoy, B. (2012). Cognitive analysis of experts and novices concept mapping processes,(Uzman ve deneyimsiz kullanıcıların kavram haritası oluşturma süreçlerinin bilişsel analizi). Doktora Tezi ODTÜ Sosyal Bilimler Enstitüsü, Ankara.

Ergin, A. ve Birol, C. (2014). Eğitimde İletişim. 7.Baskı, Ankara: Anı.

Erol, Z. (2006). Sınıf öğretmenlerinin sınıf yönetimi uygulamalarına ilişkin görüşleri. Yüksek lisans tezi, Afyon Kocatepe Üniversitesi Sosyal Bilimleri Enstitüsü, Afyonkarahisar.

Fleming, N. (2001). Teaching and learning styles: VARK Strategies. Honolulu Community College, 25 Mayıs 2015 tarihinde http://www.vark-learn.com/ english/index.asp. VARK Öğrenme Stili Web Sitesi. http://www.vark-learn. com adresinden alınmıştır. 
Fleming, N. (2012) .Teaching And Learning Styles VARK Strategies, Revised and reprinted April 2012, Lyttelton, New Zealand: The Software Workshop: 25 Mayıs 2015 tarihinde www.varklearn.com adresinden alınmıştır.

Fleming, N. D. (1995). I'm different; not dumb. models of presentation (VARK). Zemler, A (Ed.). Inthetertiary classrooom. proceedings of the 1995. Annual Conference of The Higher Education and Research Development Society of Australasia (HERDSA). 18, 308-311.

Fleming, N. D. ve Mills, C. (1992). Not another inventory, rather a catalyst for reflection. To Improve the Academy, 11: 137-155.

Fleming, N. ve Bonwell, C.C. (2001). How do I learnbest, a students' guide torm proved learning,Version 3,0. New Zealand: Christchurch.

Gilakjani, A.P., (2012). Visual, Auditory, Kinaesthetic Learning StylesandTheirImpacts on English Language Teaching. Journal of Studies in Education, 2(1), 104114, 25 Mayıs 2015 tarihinde http://dx.doi.org/10.5296/jse.v2i1.1007 adresinden alınmıştır.

Good, T. ve Brophy, J. (2006). Looking in classrooms. New York: Harper Collins.

Günay, K. (2003). Sınıf yönetiminde öğretmenlerin iletişim becerilerinin değerlendirilmesi. Yüksek Lisans Tezi, Çukurova Üniversitesi Sosyal Bilimler Enstitüsü, Adana.

Gürbüz, S. ve Şahin, F. (2015). Sosyal bilimlerde nitel araştırma yöntemleri: Felsefe Yöntem Analiz. 2. Baskı, Ankara: Seçkin.

Gürgen, H. (1997). Örgütlerde iletişim kalitesi. İstanbul: Rota.

Güven, M. (2004). Öğrenme stilleri ile öğretme stratejileri arasındaki ilişki. Doktora Tezi, Anadolu Üniversitesi Eğitim Bilimleri Enstitüsü, Eskişehir.

Hawk, T. F. ve Shah, A. (2007). Using Learning Style Instruments to Enhance Student Learning. Decision Sciences Journal of Innovative Education, 5 (1).1-19, 25 Mayıs 2015 tarihinde http://onlinelibrary.wiley.com/doi/10.1111/j.15404609.2007.00125.x/pdf adresinden alınmıștır

Hogan, R. L. (2009). Assessment of technology graduate students' learning preference styles utilizing themyers-briggs type indicator. Journal of Industrial Technology, 25(1), 1-7.

Kaşıçç, E. (2004). Beden dili. İstanbul: Hayat.

Kısaç, İ. (2004). Öğretmen öğrenci iletişimi. Emin Karip (Ed.). Sınıf Yönetimi içinde. Ankara: Pegem.

Leite, W. L., Svinicki, M. ve Shi, Y. (2010). Attempted validation of thescores of the VARK: Learning styles inventory with multitrait-multimethod confirmatory factor analysis models. Educationaland Psychological Measurement, 70(2), 323-339.

Martin, N. K., Yin, Z., \& Baldwin, B. (1998). Construct validation of the attitudes and beliefs on classroom control inventory. Journal of Classroom Interaction, 33(2), 615. 
Malatesta CZ, Izard CE. Perspectives on emotional development I: Differential emotions theory of early emotional development. In: Osofsky JD, editor. Handbook of infant development. 2nd ed. Wiley; New York: 1987. pp. 494554.

Öner, M. (1999). İlköğretim okulları 1.kademe öğretmenlerinin sınıfta iletişimi sağlama etkinlikleri. Yüksek Lisans Tezi, Marmara Üniversitesi Fen Bilimleri Enstitüsü, İstanbul.

Özbent, S. (2007). Sınıfta beden dili, Gazi Eğitim Fakültesi Dergisi, 27(2), 259-289.

Özer, K. (2015). İletişimsizlik becerisi. (12.Basım), İstanbul: Galata.

Pehlivan, K. (2005). Öğretmen adaylarının iletişim becerisi algıları üzerine bir çalışma. Muğla Üniversitesi Eğitim Fakültesi Eğitim Bilimleri Dergisi, 3, 1-14.

Pektaş, S. (1998). Sözel olmayan öğretmen davranışlarının öğretime etkilerinin değerlendirmesi. Doktora tezi, Ankara Üniversitesi Sosyal Bilimler Enstitüsü, Ankara.

Pernice, K., ve Nielsen, J. (2009). Eye tracking methodology: How to conduct and evaluate usability studies using eye tracking. Nielsen Norman Group. 12 Kasim 2013 tarihinde tarihinde http://www.useit.com/eyetracking/methodology adresinden alınmıștır.

Poon Teng Fatt, J., \& Teng Joo, N. (2001). Learning styles: implications for design and technology education. Management Research News, 24(5), 24-37.

Puyleart, F. R. (2006). Development and Analysis of Dynamic Modeling of a Residential Air Conditioner Compressor Motor for use in Power Grid Studies (Doctoral dissertation, University of Idaho).

Saracaloğlu, A. S., Yenice, N., ve Karasakaloğlu, Ö. G. D. N. (2009). Öğretmen Adaylarının İletişim ve Problem Çözme Becerileri İle Okuma İlgi ve Alışkanlıkları Arasındaki İlişki (pp. 167-185). Yüzüncü Yıl Üniversitesi Eğitim Fakültesi Dergisi, 6(2).

Senemoğlu, N. (2012). Gelişim öğrenme ve öğretim. 21.Baskı, Ankara: Pegem Akademi.

Siegel, C.M. ve Gregora, A.W., (1985). Communication skills of elderlyadults. Commun Disord, 18, 485-494.

Şeker, A. (2000). Sınıf öğretmenlerinin iletişim becerileri ile sınıf atmosferi arasındaki iliş̧kinin çeşitli değişkenler açısından incelenmesi. Yüksek Lisans Tezi, Selçuk Üniversitesi Sosyal Bilimler Enstitüsü, Konya.

Vatansever, H.B., (2015). Eğitim ortamında öğretmen öğrenci iletişimi. Akademik Sosyal Araştırmalar Dergisi, Y11: 3, Sayı: 18, Aralık, s. 262-285.

Wheeler, P. (2001). TheMyers-Briggs Type Indicator and application stoaccounting education and research. Issues in Accounting Education, 16(1), 125-150.

Williams, C. C. ve Ward J. M. (2003). The face inversion effect is not a consequence of aberrant eye movements. Memory \& Cognition, 35, 1977-1985.

Yavuzer, Y. ve Koç, M. (2002). Eğitim fakültesi öğrencilerinin öğretmen yetkinlikleri üzerine bir değerlendirme. Niğde Üniversitesi Eğitim Fakültesi Dergisi, 1(1), 35-43

Yıldırım, A. ve Şimşek, H. (2013). Sosyal bilimlerde nitel araştırma yöntemleri. 9. Baskı, Ankara: Seçkin. 
